Для цитирования: Максимова В.П., Макусь Ю.В., Усалка О.Г., Лылова Е.С., Бугаева П.С., Жидкова Е.М., Федоров Д.А., Лизогуб О.П., Лесовая Е.А., Белицкий Г.А., Якубовская М.Г., Кирсанов К.И. Эпигенетические эффректы энзастаурина - новый аспект в механизме действия противоопухолевого препарата из группы ингибиторов протеинкиназ. Сибирский онкологический журнал. 2020; 19(4): 67-78. - doi: 10.21294/1814-4861-2020-19-4-67-78.

For citation: Maksimova V.P., Makus J.V., Usalka O.G., Lylova, E.S., Bugaeva P.E., Zhidkova E.M., Fedorov D.A., Lizogub O.P., Lesovaya E.A., Belitsky G.A., Yakubovskaya M.G., Kirsanov K.I. Epigenetic effects of enzastaurin A new aspect in the mechanism of action of an anticancer drug from protein kinase inhibitors. Siberian Journal of Oncology. 2020; 19(4): 67-78. - doi: 10.21294/1814-4861-2020-19-4-67-78.

\title{
EPIGENETIC EFFECTS OF ENZASTAURIN - A NEW ASPECT IN THE MECHANISM OF ACTION OF AN ANTICANCER DRUG FROM PROTEIN KINASE INHIBITORS
}

\author{
V.P. Maksimova1, J.V. Makus ${ }^{2}$, O.G. Usalka³ ${ }^{3}$ E.S. Lylova ${ }^{1}$, P.E. Bugaeva ${ }^{3}$, \\ E.M. Zhidkova1, D.A. Fedorov³, O.P. Lizogub³ ${ }^{3}$ E.A. Lesovaya ${ }^{1,4}$, G.A. Belitsky ${ }^{1}$, \\ M.G. Yakubovskaya ${ }^{1}$, K.I. Kirsanov ${ }^{1,5}$
}

N.N. Blokhin National Medical Research Center of Oncology, Moscow, Russia ${ }^{1}$ 24, Kashirskoe shosse, 115478, Moscow, Russia. E-mail: lavarvar@gmail.com ${ }^{1}$ MIREA - Russian Technological University, Moscow, Russia²

86, Vernadsky prospect, 119571, Moscow, Russia. E-mail: ymakus@yandex.ru² I.M. Sechenov First Moscow State Medical University (Sechenov University), Moscow, Russia ${ }^{3}$ 8, Trubetskaya Street, 119991, Moscow, Russia. E-mail: ousalka@mail.ru³

I.P. Pavlov Ryazan State Medical University, Ryazan, Russia ${ }^{4}$

9, Vysokovoltnaya Street, 390026, Ryazan, Russia. E-mail: lesovenok@yandex.ru4

RUDN University, Moscow, Russia ${ }^{5}$

6, Miklukho-Maklaya Street, 117198, Moscow, Russia. E-mail: kkirsanov85@yandex.ru5

Abstract

The purpose of the study was to analyze the ability of five antitumor drugs from the pharmaceutical group of protein kinase inhibitors (gefitinib, imatinib, pazopanib, ponatinib and enzastaurin) to reactivate the expression of the epigenetically silenced GFP in HeLa TI cells, and to estimate the effect of epigenetically active drugs on: 1) acetylation and methylation of histones $\mathrm{H} 3$ and $\mathrm{H} 4$; 2) integral DNA methylation; 3) activity of HAT and HDAC1 enzymes; 4) expression levels of the genes encoding epigenetic regulation enzymes (DNMT1, DNMT3A, DNMT3B; SIRT1, HDAC1; SETD1A, SETD1B, SUV42OH1, SUV42OH2, SUV39H1, SUV39H2). Material and Methods. The epigenetic activity of antitumor drugs was determined using the HeLa TI test system, a population of HeLa cells with the retroviral vector containing the epigenetically silenced GFP. The level of integral DNA methylation was analyzed using Mspl/Hpall methyl-sensitive restriction analysis. Histone modifications were analyzed by Western blotting with antibodies to acetylated and methylated histones $\mathrm{H} 3$ and H4. The total activity of HAT enzymes was analyzed using Histone Acetyltransferase Activity Assay Kit. Expression of the epigenetic enzyme genes was analyzed using real-time quantitative RT-PCR. Results. It was shown that only the enzyme inhibitor $C \beta$ protein kinase enzastaurin had the ability to reactivate the expression of epigenetically silenced GFP in the HeLa TI cells. We showed that under the action of enzastaurin, the level of integral DNA methylation and expression of DNMT3A and DNMT3B DNA methyltransferase genes decreased. It was also found that enzastaurin reduced the expression levels of histone deacetylases HDAC1 and SIRT1, but did not affect the activity and expression levels of histone acetylases, the level of histone methylation (H3K4me3, H3K9me3, H3K27me3, H4K20me3), and the level of expression of the histone methyltransferases (SUV39H1, SUV39H2, SUV420H1, SUV420H2, SETD1A u SETD1B). Conclusion. The data obtained are important for clarifying the mechanisms of action of 5 protein kinase inhibitors, in particular with respect to enzastaurin, the protein kinase $C \beta$ inhibitor, for which the ability to reactivate epigenetically silent genes due to the effect on DNA methylation and histone acetylation was demonstrated.

Key words: protein kinase inhibitors, enzastaurin, epigenetic activity, HeLa TI, histone modifications, DNA methylation, HAT, HDAC. 


\title{
ЭПИГЕНЕТИЧЕСКИЕ ЭФФЕКТЫ ЭНЗАСТАУРИНА - НОВЫЙ АСПЕКТ В МЕХАНИЗМЕ ДЕЙСТВИЯ ПРОТИВООПУХОЛЕВОГО ПРЕПАРАТА ИЗ ГРУППЫ ИНГИБИТОРОВ ПРОТЕИНКИНАЗ
}

\author{
В.П. Максимова ${ }^{1}$, Ю.В. Макусь ${ }^{2}$, О.Г. Усалка ${ }^{3}$, Е.С. Лылова ${ }^{1}$, П.С. Бугаева ${ }^{3}$, \\ Е.М. Жидкова ${ }^{1}$, Д.А. Федоров ${ }^{3}$, О.П. Лизогуб ${ }^{3}$, Е.А. Лесовая ${ }^{1,4}$, \\ Г.А. Белицкий ${ }^{1}$, М.Г. Якубовская ${ }^{1}$, К.И. Кирсанов ${ }^{1,5}$
}

ФГБУ «НМИЦ онкологии им. Н.Н. Блохина» Минздрава России, г. Москва, Россия ${ }^{1}$ Россия, г. Москва, 115478, Каширское шоссе, 24. E-mail: lavarvar@gmail.com ФГБОУ ВО «МИРЭА - Российский технологический университет» ИТХТ, г. Москва, Россия ${ }^{2}$ Россия, г. Москва, 119571, Проспект Вернадского, 86. E-mail: ymakus@yandex.ru² ФГАОУ ВО «Первый МГМУ им. И.М. Сеченова» Минздрава России, г. Москва, Россия 3 Россия, г. Москва, 119991, ул. Трубецкая, 8/2. E-mail: ousalka@mail.ru³ ФГБОУ ВО «Рязанский государственный медицинский университет» Минздрава России, г. Рязань, Россия ${ }^{4}$

Россия, г. Рязань, 390026, ул. Высоковольтная, 9.

E-mail: lesovenok@yandex.ru ФГАОУ ВО «Российский университет дружбы народов», г. Москва, Россия 5 Россия, г. Москва, 117198, ул. Миклухо-Маклая, 6. E-mail: kkirsanov85@yandex.ru5

\section{Аннотация}

Цель исследования - провести анализ способности 5 противоопухолевых препаратов из фармакологической группы ингибиторов протеинкиназ (гефитиниб, иматиниб, пазопаниб, понатиниб и энзастаурин) реактивировать экспрессию эпигенетически репрессированного гена GFP в клеткаx HeLa TI, a также изучить влияние препаратов, обладающих реактивирующим эффектом, на: 1) ацетилирование и метилирование гистонов Н3 и Н4; 2) интегральное метилирование ДНК; 3) активность ферментов НАТ и HDAC1; 4) уровень экспрессии генов, кодирующих ферменты эпигенетической регуляции (DNMT1, DNMT3A, DNMT3B; SIRT1, HDAC1; SETD1A, SETD1B, SUV42OH1, SUV42OH2, SUV39H1, SUV39H2). Материал и методы. Скрининг эпигенетической активности противоопухолевых препаратов осуществляли с помощью тест-системы HeLa TI - популяции клеток HeLa с интегрированным ретровирусным вектором, содержащим эпигенетически репрессированный ген GFP. Изменение уровня интегрального метилирования ДНК анализировали с помощью метил-чувствительного рестрикционного анализа Mspl/ Hpall. Изменение уровня гистоновых модификаций анализировали методом Вестерн-блоттинг с антителами к ацетилированным и метилированным сайтам гистонов Н3 и Н4. Анализ тотальной активности ферментов семейства НАТ проводили при использовании набора реактивов для определения активности гистоновых ацетилтрансфераз. Анализ экспрессии генов эпигенетических регуляторных ферментов осуществляли с помощью метода количественной ОТ-ПЦР в реальном времени. Результаты. Показано, что среди исследуемых препаратов способностью реактивировать экспрессию эпигенетически репрессированного гена GFP в популяции HeLa TI обладает только ингибитор протеинкиназы C $\beta$ энзастаурин. Мы продемонстрировали, что при действии энзастаурина происходит снижение уровня интегрального метилирования ДНК и экспрессии генов ДНК-метилтрансфераз DNMT3A и DNMT3B. Также установлено, что энзастаурин снижает уровень экспрессии гистоновых деацетилаз HDAC1 и SIRT1, но не влияет на активность и уровни экспрессии гистоновых ацетилаз, уровень метилирования гистонов (H3K4me3, H3K9me3, H3K27me3, H4K20me3) и уровень экспрессии гистоновых метилтрансфераз (SUV39H1, SUV39H2, SUV420H1, SUV420H2, SETD1A и SETD1B). Заключение. Полученные данные важны в плане уточнения механизмов действия 5 противоопухолевых препаратов группы ингибиторов протеинкиназ, в особенности в отношении ингибитора протеинкиназы Сß энзастаурина, для которого была продемонстрирована способность реактивировать экспрессию эпигенетически молчащих генов за счет влияния на механизмы метилирования ДНК и ацетилирования гистонов.

Ключевые слова: ингибиторы протеинкиназ, энзастаурин, эпигенетическая активность, HeLa TI, гистоновые модификации, метилирование ДНК, НАТ, НDAC. 


\section{Introduction}

Disruption of epigenetic regulation, along with genetic aberrations, plays a significant role in initiation, promotion, and progression of tumor growth. Activation of proliferation, inhibition of apoptosis, intercellular interactions, and cell aging can occur during carcinogenesis as a result of changes in the profile of epigenetic modifications due to impaired histone acetylation and methylation, as well as DNA methylation [1]. These changes can be due to a mutation or dysregulation of the expression of histoneand DNA-modifying enzymes or direct inhibition of the activity of these enzymes and activation of their degradation. Epigenetic regulatory enzymes include histone acetyltransferases (HATs) and deacetylases (HDACs), histone methyltransferases (HMTs) and demethylases (HDMs), as well as DNA methyltransferases (DNMTs). Epigenetic changes are usually reversible: restoration of the activity of enzymes responsible for epigenetic regulation of transcription leads to normalization of the epigenetic profile $[2,3]$. Thus, enzymes responsible for epigenetic regulation of transcription represent targets for anticancer therapy. Low-molecular-weight compounds selectively inhibiting the enzymes of epigenetic regulation are already used for the treatment of certain types of cancer.

Currently, the use of azacitidine and decitabine, inhibitors of DNA methyltransferase (DNMT), is one of the most successful epigenetic anticancer strategies. However, these drugs have a number of limitations. Firstly, since these molecules are modified by cytosine analogues, they can be mistakenly incorporated into nascent DNA and RNA, which increases the probability of mutations. Secondly, azacitidine and decitabine are highly toxic and of low chemical stability [4]. Nowadays, the properties of non-nucleoside inhibitors of DNMTs selectively interacting with the catalytic sites of enzymes are actively studied; these inhibitors include RG108, Psammaplin, hydralazine, and procainamide, with non-nucleoside inhibitors being less effective than azacitidine [1]. Histone deacetylase (HDAC) inhibitors are a class of compounds that can modulate the epigenetic regulation of gene expression via histone acetylation. HDAC inhibitors are the most commonly used epigenetically active agents in the treatment of cancer [5]. Over the past few years, a series of clinical trials on the use of HDAC inhibitors in antitumor therapy have begun. By the beginning of 2020, five histone deacetylase inhibitors were approved by the US Food and Drug Administration (FDA) for the treatment of oncological diseases: vorinostat, romidepsin, belinostat, panobinostat, and chidamide [6]. Moreover, a series of perspective agents are currently under the phase II/III clinical trial: valproic acid, mocetinostat, entinostat, trichostatin A, phenylacetate, phenylbutyrate, tacedinaline, etc. [1]. Over the past 15 years, an essential role of impaired activity of histone methyltransferases (HMTs) in tumorigenesis has been demonstrated. For this reason, another class of compounds, namely HMT inhibitors, was introduced among epigenetic modulators [7]. Other important antitumor targets are methyltransferases SUV391H, EZH2, MLL, Nsd1, and RIZ. A series of selective HMT inhibitors are currently under the phase I/II clinical study: pinometostat, GSK2816126, CPI-1205, TCP, and 4SC-202. In 2020, the FDA approved a selective inhibitor of EZH2 methyltransferase, tazemetostat, for the treatment of metastatic or locally advanced epithelioid sarcoma that cannot be completely resected [8]. Thus, the search for new epigenetically active drugs is a promising trend in the field of chemotherapy of oncological diseases.

The search, development, as well as preclinical and clinical studies of a new drug require a lot of funding and last 5-15 years. For this reason, a promising trend in pharmacology in general and, in particular, and oncology is the drug repurposing. The search for agents with inhibitory activity against HDAC, DNMT, and HMT among the approved drugs that are already used in medical practice is undertaken. For this reason, protein kinase inhibitors approved for the treatment of various tumors (gefitinib, imatinib, pazopanib), as well as drugs undergoing clinical trials (ponatinib and enzastaurin), were chosen as the object of the current study. The multi-target action of these small molecules allowed suggesting their potential effect on the system of epigenetic regulation of transcription [9]. Another reason for choosing this group of drugs was the ability of natural polyphenolic compounds known as modulators of epigenetic regulatory enzymes to inhibit protein kinases [10].

Identification of epigenetically active agents among numerous drugs was complicated by the lack of available test systems that allow quick and inexpensive screening of drugs for their ability to exert an epigenetic effect [11]. For this, we decided to use HeLa TI cells, which were obtained for the study of the mechanisms of retroviral epigenetic silencing in the laboratory of prof. A.M. Skalka in 2007. HeLa TI is a population of cells carrying a retroviral vector integrated into various sites of the genome and containing epigenetically repressed GFP reporter gene. Analysis of the mechanisms of the GFP reporter gene suppression revealed the involvement of more than 15 different factors of epigenetic regulation of transcription in this process $[12,13]$. HeLa TI cells are sensitive to HDAC and DNMT, as well as HMT inhibitors [14].

The aim of the current work was to study the ability of five antitumor protein kinase inhibitors to reactivate the expression of epigenetically repressed GFP, as well as to analyze the effect of epigenetically active drugs on: 1) acetylation and methylation of histones $\mathrm{H} 3$ and $\mathrm{H} 4$; 2) integrated DNA methylation; 3) HAT and HDAC1 enzyme activity; 4) expression level of the genes encoding for epigenetic regulatory enzymes. 


\section{Material and methods}

\section{Cell lines and reagents}

The following cell cultures were used in the study: HeLa TI, a polyclonal population of HeLa cells containing a vector integrated into genome (derived from avian sarcoma retrovirus) carrying epigenetically repressed GFP; CasKi, an epidermoid cervical carcinoma cell line, characterized by higher level of DNA methylation than HeLa cells $[15,16]$. The cells were cultured in DMEM medium supplemented with $10 \%$ fetal bovine serum (Biosera), L-glutamine (2 mM, PanEco, Russia), and penicillin/streptomycin mixture (50 units, PanEco, Russia) in $5 \% \mathrm{CO}_{2}$ at $37^{\circ} \mathrm{C}$. Upon reaching $80 \%$ confluence, the cells were passaged at a rate of 1:5.

For the study, the following drugs were selected from the pharmacological group of protein kinase inhibitors: gefitinib, imatinib, pazopanib, ponatinib, and enzastaurin (all provided by Sellek). Compounds with epigenetic activity that were used as positive controls, namely trichostatin A and vorinostat (histone deacetylase inhibitors), as well as azacitidine (inhibitor of DNA methyltransferases) were obtained from Sigma Aldrich. All of the above-mentioned compounds were dissolved in DMSO to obtain stock solutions; the solvent concentration did not exceed $0.1 \%$ in the culture medium.

\section{Evaluation of drug cytotoxicity}

Cytotoxicity of protein kinase inhibitors was measured using the MTT test [17]. The cells were seeded at $5 \times 10^{3}$ cells per well in 96-well flat-bottom plates and incubated overnight. Next, serial dilutions of the preparations were added in triplicate and incubated for $72 \mathrm{~h}$ under standard conditions $\left(37^{\circ} \mathrm{C}, 5 \% \mathrm{CO}_{2}\right)$. After this, the cells were treated with 3-[4,5-dimethylthiazol-2-yl]-2,5-diphenyltetrazolium bromide (MTT, Dia-M, Russia). After four hours of exposure to MTT, the medium was removed, and $100 \mu \mathrm{l}$ of DMSO was added. The optical density of the solution was measured at $540 \mathrm{~nm}$ using a Multiskan Sky microplate spectrophotometer (Thermo Scientific). The cytotoxicity index was determined using $0.1 \%$ DMSO as a negative control.

\section{Analysis of the drug ability to reactivate the ex- pression of epigenetically repressed GFP gene in the HeLa TI cell test system}

Flow cytometry was used to analyze the ability of the drugs to reactivate the expression of epigenetically repressed GFP. Cells were seeded in 24-well plates at $2.5 \times 10^{4}$ cells per well and treated with gefitinib, imatinib, pazopanib, ponatinib $(25 \mu \mathrm{M} \mathrm{IC}$ for all drugs) and enzastaurin $\left(\mathrm{IC}_{20}, 30 \mu \mathrm{M}\right) 24 \mathrm{~h}$ later. After 24-hour incubation, the medium in the plates was replaced with fresh one, and the cells were incubated for another $48 \mathrm{~h}$. Next, the cells were detached from the culture plates using $0.25 \%$ trypsin-EDTA solution (PanEco, Russia). The relative number of GFP-positive cells was assessed using BD FACSCanto ${ }^{\mathrm{TM}}$ II flow cytometer. Cells treated with trichostatin A (TCA), a histone deacetylase inhibitor, were used as a positive control. An antitumor drug was considered epigenetically active if GFP reactivation was observed in $12 \%$ of the cells or more. The proportion of GFP-positive cells among $0.01 \%$ DMSO-treated cells did not exceed $4.5-5 \%$.

\section{Histone extraction}

Cells were seeded in 60-mm Petri dishes $\left(3 \times 10^{5}\right.$ cells per dish) and incubated overnight in standard conditions. Next, enzastaurin $(30 \mu \mathrm{M})$ was added, and the cells were incubated for $4 \mathrm{~h}, 12 \mathrm{~h}, 24 \mathrm{~h}$, and $72 \mathrm{~h}$. Abcam acid extraction protocol and trichloroacetic acid precipitation protocol presented by Shechter et al. [18] were used for obtaining a histone fraction.

\section{Analysis of the effect of enzastaurin on the level of histone modifications}

Western blotting was used to analyze the effect of enzastaurin on acetylation and methylation of $\mathrm{H} 3$ and $\mathrm{H} 4$ histones. Histone proteins were separated by $15 \%$ PAGE and transferred to nitrocellulose membranes with a pore size of $0.22 \mu \mathrm{m}(100 \mathrm{~mA}, 40 \mathrm{~min})$. The membranes were then blocked in TBST buffer containing $5 \%$ skim milk at room temperature for $30 \mathrm{~min}$. Abcam antibodies to the following histone modifications were used in the study: H3acK9 + H3acK14 + H3acK18 + H3acK23 + H3acK27 (ab47915), H3K9me3 (ab8898), H3K4me3 (ab8580), H4K20me3 (ab9053), and H4 (ab10158). Membranes were incubated with primary antibodies at $+4{ }^{\circ} \mathrm{C}$ overnight, washed with TBST and incubated with secondary antibodies (ab6721). For protein detection, Clarity ${ }^{\mathrm{TM}}$ Western ECL Substrate visualization reagent (Bio-Rad) and ImageQuant LAS 4000 digital imaging system (GE Healthcare) were used. Densitometric analysis of the blots was performed using ImageJ software. The results were calculated as described by Li et. al. [19]. All experiments were performed in triplicate.

\section{Preparation of nuclear extracts}

HeLa TI cells were seeded in 60-mm Petri dishes $\left(8 \times 10^{5}\right.$ cells per dish). After the cells were attached to the substrate, they were incubated with enzastaurin $(30 \mu \mathrm{M})$ for $24 \mathrm{~h}$. The nuclear fraction of the cells was obtained according to the Abcam protocol (Nuclear extraction and fractionation protocol, https://www. abcam.com/protocols/nuclear-extraction-protocol-nuclear-fractionation-protocol). Cells were washed with PBS, passed through a $26 \mathrm{G}$ needle and centrifuged at $720 \mathrm{~g}$ for $5 \mathrm{~min}$ for precipitation of a nuclear fraction. Then, the precipitate was resuspended and passed through a $23 \mathrm{G}$ needle, centrifuged in the same conditions, and the resulting precipitate was resuspended in $\mathrm{ddH}_{2} \mathrm{O}$. For DNA destruction, the suspension was sonicated for 3 seconds at an amplitude of $20 \mu \mathrm{m}$ using a Soniprep 150 Plus ultrasonic disintegrator (MSE). 


\section{The effect of enzastaurin on HAT activity}

The effect of enzastaurin on the overall activity of HAT was analyzed using Histone Acetyltransferase Activity Assay Kit (ab65352, Abcam) according to the manufacturer's instructions. A total of $50 \mu \mathrm{g}$ of nuclear extract was incubated with HAT I/II and NADHgenerating enzyme in HAT assay buffer for $4 \mathrm{~h}$ at 37 ${ }^{\circ} \mathrm{C}$. The optical density was measured at $450 \mathrm{~nm}$ in a Multiskan Sky microplate spectrophotometer (Thermo Scientific), and an active nuclear extract was used as a positive control. HAT activity was expressed in $\mu \mathrm{M} / \mu \mathrm{g}$ as indicated by the manufacturer, after which the activity was calculated in \% relative to the negative control. All experiments were performed in triplicate.

\section{The effect of enzastaurin} on the level of $\mathrm{HDAC1}$

To analyze the effect of enzastaurin on the level of HDAC1, the nuclear fraction of the proteins was separated by $10 \%$ PAGE, and then standard Western blotting was performed (as previously described). Abcam antibodies to HDAC1 (ab53091) and H3 histone (ab18521), which served as a load control, were used in the study. Protein detection was performed as described above. Densitometric analysis of the blots was conducted using ImageJ software. All experiments were performed in triplicate.

\section{The effect of enzastaurin}

\section{on the integrated DNA methylation}

The effect of enzastaurin on integrated DNA methylation was analyzed using a commercial EpiJet kit (K1441, Thermo Scientific) based on methylationsensitive HpaII/MspI restriction assay. CasKi cells were seeded in 6 -well plates $\left(1.5 \times 10^{5}\right.$ cells per well). After the cells were attached to the substrate, they were incubated with enzastaurin $(2 \mu \mathrm{M})$ or the demethylating agent azacitidine $(1 \mu \mathrm{M})$ as a positive control for $72 \mathrm{~h}$. After every $24 \mathrm{~h}$ of incubation, half of the culture medium was replaced with fresh medium, and the drugs under study were added to the concentration indicated above. Next, genomic DNA was extracted from the cells using the GeneJET Genomic DNA Purification Kit (K0721, Thermo Scientific), and the enzymatic reaction with HpaII and MspI restriction enzymes was performed according to the manufacturer's protocol. Restriction products were analyzed by $1 \%$ agarose gel electrophoresis and detected on a Typhoon 9400 scanner (GE Healthcare). Densitometric analysis of the obtained images was carried out using the ImageJ software. All experiments were performed in triplicate.

\section{The effect of enzastaurin}

\section{on the genes of chromatin-modifying enzymes}

Analysis of the expression level of chromatin-modifying enzyme genes was carried out using quantitative real-time RT-PCR. Cells were seeded in 60-mm Petri dishes $\left(8 \times 10^{5}\right.$ cells per dish $)$ and treated with enzastau- rin at concentrations of 30,15 and $7.5 \mu \mathrm{M}$ after $16-20$ $\mathrm{h}$. After $24 \mathrm{~h}$, the cells were removed from the substrate, and the total RNA was extracted using the GeneJET RNA Purification Kit (Thermo Scientific). Next, $2 \mu \mathrm{g}$ of cDNA were obtained using the reverse transcription kit (Synthol). Sequences of the primers for PCR are presented in table 1. Real-time PCR was performed using a reagent kit for RT-PCR (Syntol). Data were analyzed by calculating the threshold cycle value $(\mathrm{Ct})$ with normalization to the expression of the housekeeping gene $A C T B$ in each sample. Next, the samples were normalized to the negative control $(0.1 \% \mathrm{DMSO})$.

\section{Таблица 1/Table 1 \\ Nucleotide sequences of the primers used in the study \\ Нуклеотидные последовательности используемых праймеров}

\begin{tabular}{|c|c|c|}
\hline $\begin{array}{l}\text { Название/ } \\
\text { Name }\end{array}$ & \multicolumn{2}{|c|}{ Последовательность 5'-3'/Sequences 5'-3' } \\
\hline \multirow{2}{*}{$H D A C 1$} & CACCCATTCTTCCCGTTCTT & \\
\hline & GGCATTTCAGGAGTTTGTCTTAT & Reverse \\
\hline \multirow{2}{*}{ SIRT1 } & GCAAAGAAGAAACAGCATTGAAG & Forward \\
\hline & ATGAATGCTGAGTTGCTGGAT & Reverse \\
\hline \multirow{2}{*}{ DNMT1 } & AGCACAGAAGTCAACCCAAA & Forward \\
\hline & TGCGTCTCTTCTCCTCCTTT & Reverse \\
\hline \multirow{2}{*}{ DNMT3A } & AGCCCAAGGTCAAGGAGATT & Forward \\
\hline & TACGCACACTCCAGAAAGC & Reverse \\
\hline \multirow{2}{*}{ DNMT3B } & CAACAGCATCGGCAGGAA & Forward \\
\hline & GTCCTCTGTGTCGTCTGTGA & Reverse \\
\hline \multirow{2}{*}{ HAT1 } & GCGATAGAGGCACAACAGAA & \\
\hline & TGTATTGTTCGGCATCACTCA & Reverse \\
\hline \multirow{2}{*}{$C R E B B P$} & CTGGCAGACCTCGGAAAGAA & \\
\hline & CTGGCGCCGCAAAAACT & Reverse \\
\hline \multirow{2}{*}{ EP300 } & & \\
\hline & TGCTGGTTGTTGCTCTCATC & Reverse \\
\hline \multirow{2}{*}{ SETDIA } & GCGGGCTATTCTCTCACTTG & \\
\hline & & Reverse \\
\hline \multirow{2}{*}{ SETDIB } & & \\
\hline & AGACACACAACGGAAACACT & Reverse \\
\hline \multirow{2}{*}{ SUV420H1 } & CCCGTGTAGCATAAAAGCAGC & Forward \\
\hline & CCAGTTTCACCAAGGAACCAG & Reverse \\
\hline \multirow{2}{*}{ SUV420H2 } & CGTGCTTGGAAGAAGAATGA & Forward \\
\hline & GCAGTCATGGTTGATGAAGG & Reverse \\
\hline \multirow{2}{*}{ SUV39H1 } & GCTAGGCCCGAATGTCGTTA & Forward \\
\hline & TAGAGATACCGAGGGCAGGG & Reverse \\
\hline \multirow{2}{*}{ SUV39H2 } & GCAGGACGAACTCAACAGAA & Forward \\
\hline & CAACCAAAGGTGGCTTCATT & Reverse \\
\hline
\end{tabular}


Relative expression of the genetic locus (Exp) was calculated using the $2-\Delta \Delta \mathrm{Ct}$ method.

\section{Statistical methods}

Statistical analysis of the data was performed using Microsoft Excel. To assess the significance of differences between the groups, including the expression levels, a paired two-sample Student's t-test with a level of statistical significance of $\mathrm{p}<0.05$ was used.

\section{Results and Discussion}

Impaired regulation of protein kinase activity leads to various pathophysiological disorders, in particular, hyperproliferation of tumor cells, stimulation of inva-

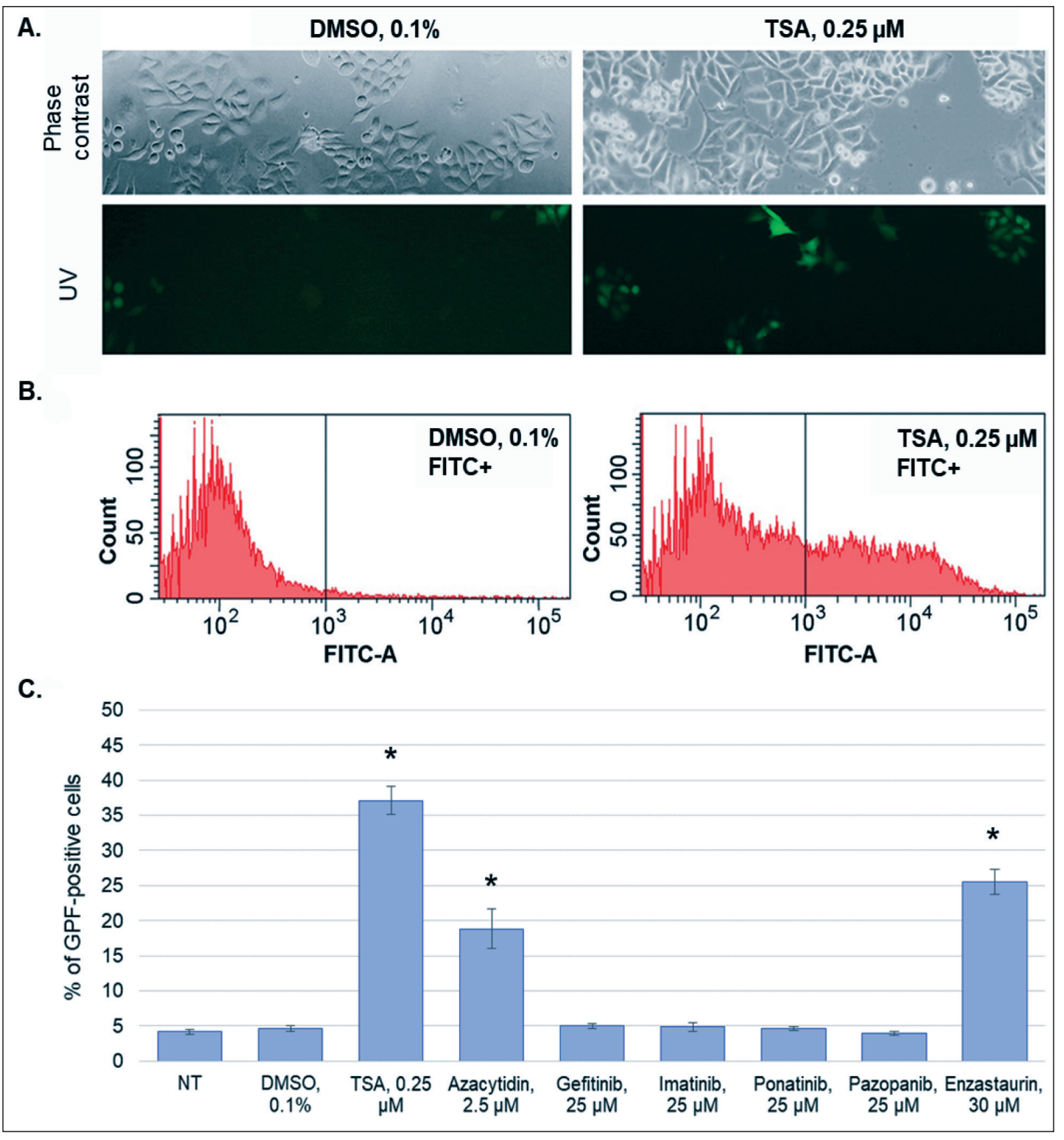

Рис. 1. Анализ эпигенетической активности противоопухолевых препаратов из группы ингибиторов протеинкиназ в тест-системе HeLa TI: A, B. Анализ доли GFP-положительных клеток в популяции HeLa TI при обработке 0,1 \% ДMCO и при обработке ингибитором гистоновых деацетилаз трихостатином А с помощью флуоресцентной микроскопии (А) и проточной цитофлуориметрии (B). С. Результаты проточной цитофлуориметрии для исследуемых препаратов. Все результаты представлены в виде M \pm SD. Примечание: * - различия статистически значимы по сравнению с контролем $(p<0,05)$

Fig. 1. Analysis of the epigenetic activity of antitumor drugs of the group of protein kinase inhibitors in the HeLa TI cell test system: A, B. Analysis of the proportion of GFP-positive cells in the HeLa TI cell population treated with $0.1 \%$ DMSO and histone deacetylase inhibitor trichostatin A (TSA) by fluorescence microscopy (A) and flow cytometry (B). C. Flow cytometry results of the drug analysis. All data are presented as $\mathrm{M} \pm \mathrm{SD}$.

Notes; ${ }^{*}$ - differences are statistically significant as compared to the control $(p<0.05)$ 
sion and metastasis [20]. In this regard, inhibition of protein kinases is an effective approach to treat cancer. To date, 37 drugs of this group have been approved for the treatment of various oncological diseases, including non-small cell lung carcinoma, acute lymphoblastic leukemia, chronic myeloid leukemia, breast cancer, etc. [21]. The ability of protein kinase inhibitors to influence gene expression via epigenetic regulation has not been studied yet. The list of the drugs used in the current study includes agents that were approved for antitumor therapy: (1) gefitinib, a selective inhibitor of the epidermal growth factor receptor (EGFR) tyrosine kinase used for the treatment of non-small cell lung cancer; (2) imatinib, a Bcr-Abl tyrosine kinase inhibitor used to treat chronic myeloid leukemia; (3) pazopanib, a non-selective tyrosine kinase inhibitor, which is active against vascular endothelial growth factor receptors (VEGFRs), platelet-derived growth factor receptors (PDGFRs), fibroblast growth factor receptors (FGFRs) and used in the treatment of kidney cancer; as well as two drugs that are currently undergoing clinical trials, namely (4) ponatinib and (5) enzastaurin. Ponatinib is a multi-target inhibitor of tyrosine kinases; it was shown to exert antitumor activity against chronic myeloid leukemia and acute lymphoblastic leukemia [22, 23]. Enzastaurin is a selective inhibitor of $C \beta$ protein kinase and currently undergoing phase III clinical trials in patients with diffuse large B-cell lymphoma [24].

At the first stage, we analyzed the ability of nontoxic doses of gefitinib, imatinib, pazopanib, ponatinib, and enzastaurin to reactivate the expression of epigenetically repressed GFP in HeLa TI test system. As shown by flow cytometry, treatment with enzastaurin results in a 6-fold increase in the proportion of GFPpositive cells. No statistically significant increase in the number of GFP-expressing cells was detected for the other drugs (Fig. 1).

The obtained data indicate that, of the tested drugs, only enzastaurin has an effect on epigenetic regulation of gene expression. For this reason, further work was aimed at analysis of the mechanisms of the epigenetic effect of enzastaurin, in particular, at the study of its effect on the profile of histone modifications and DNA methylation.

Histone acetylation/deacetylation is one of the key mechanisms of chromatin remodeling. Acetylation of histones at lysine residues neutralizes the positive charge of the amino acid and reduces the interaction between the $\mathrm{N}$ termini of histones and DNA phosphate groups [3]. This, in its turn, promotes the transformation of silent heterochromatin into transcriptionally active euchromatin. A decrease in the level of lysine acetylation at positions $\mathrm{H} 3 \mathrm{~K} 9, \mathrm{H} 3 \mathrm{~K} 14, \mathrm{H} 3 \mathrm{~K} 18$, and H4K16 was shown to be associated with promotion and progression of tumor growth, as well as with tumor resistance to chemotherapy [25].

Changes in the global level of $\mathrm{H} 3$ histone acetylation caused by enzastaurin were analyzed by Western blotting using antibodies to a number of acetylation sites $(\mathrm{H} 3 \mathrm{acK} 9+\mathrm{H} 3 \mathrm{acK} 14+\mathrm{H} 3 \mathrm{acK} 18+\mathrm{H} 3 \mathrm{acK} 23+\mathrm{H} 3 \mathrm{a}$ cK27). The obtained results indicate that the effect of enzastaurin results in a more than 1.5 -fold increase in the level of histone acetylation (Fig. 2A).

Changes in the level of histone acetylation are the result of an altered balance in the activity of histone acetyltransferases (HATs) and deacetylases (HDACs). We demonstrated that treatment of the cells with enzastaurin did not change the activity of histone acetyltransferases and did not affect the expression level of the corresponding genes (Fig. 2B, 2C).

Among histone deacetylases, enzymes HDAC1 and HDAC2 [26], as well as SIRT1 deacetylase [27], had the greatest contribution to the regulation of histone modifications. We demonstrated that enzastaurin resulted in a decreased $H D A C 1$ expression both at the mRNA and protein levels (1.8-fold decrease). A slight (1.5-fold) decrease in SIRT1 expression was also shown (Fig. 2D, 2E).

In contrast to acetylation, methylation of histones $\mathrm{H} 3$ and $\mathrm{H} 4$ does not change the total charge of the molecule, and the effect on transcription occurs due to interaction of the effector molecules with modified bases [1]. At the same time, methylation of the amino acid residues of histones can lead to both gene silencing (lysine methylation at H3K9, H3K27, and H4K20 positions) and to induction of gene expression (lysine methylation at $\mathrm{H} 3 \mathrm{~K} 4, \mathrm{H} 3 \mathrm{~K} 36$, and $\mathrm{H} 3 \mathrm{~K} 79$ positions), that depends on the modification site and the number of methyl groups (mono-, di-, and trimethylation) [28]. Using Western blotting, we analyzed the effect of enzastaurin on the following sites: $\mathrm{H} 3 \mathrm{~K} 4 \mathrm{me} 3$, H3K9me3, H4K20me3; no effect of enzastaurin on the methylation level of these sites was observed (Fig. $3 \mathrm{~A})$. The data obtained are consistent with the results of real-time PCR, which indicate that the drug has no effect on the expression level of the corresponding histone methyltransferases: (1) SUV39H1 and SUV39H2 (methylation at the H3K9 site), (2) SUV42OH1 and SUV42OH2 (methylation at H4K20), and (3) SETD1A и SETD1B (methylation of the H3K4 site) (Fig. 3B).

Another major epigenetic mechanism of gene expression regulation is DNA methylation. Hypermethylation of the promoters of tumor suppressor genes inhibits their expression, and, by this way, contributes to the initiation of carcinogenesis and tumor progression [29, 30]. Methylation-sensitive HpaII/MspI restriction assay demonstrated that enzastaurin decreased the level of DNA methylation, which was indicated by a higher degree of DNA cleavage by the methylationsensitive restriction enzyme HpaII (55.8 \% compared to the control) (Fig. 4A, 4B). Moreover, the demethylation effect of the drug was comparable with the effect of the positive control 5-azacitidine. These results were consistent with real-time PCR data concerning the drug influence on the expression level of DNA methyltransferases. Enzastaurin was shown to reduce the mRNA level of de novo DNA methyltransferases 
A.
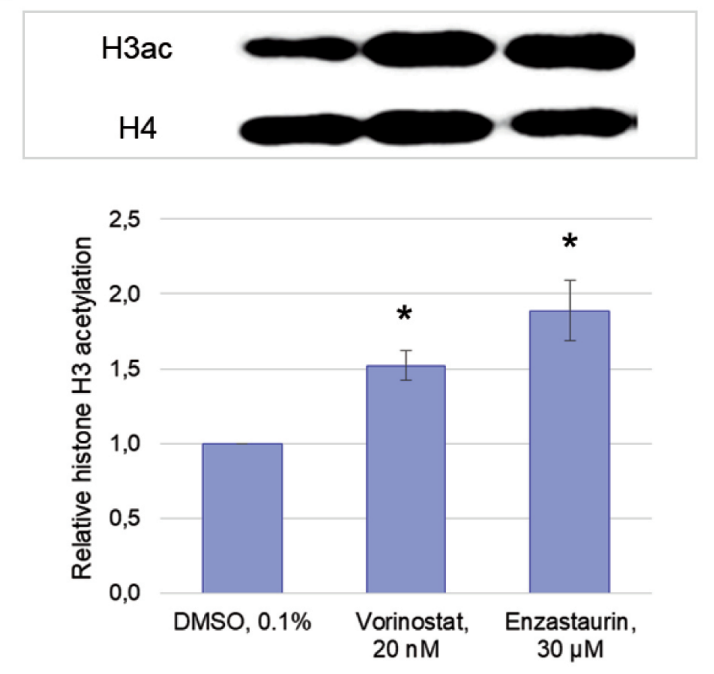

B.

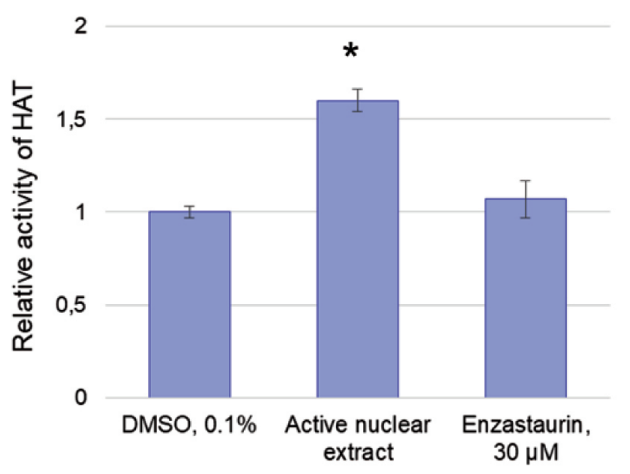

C.

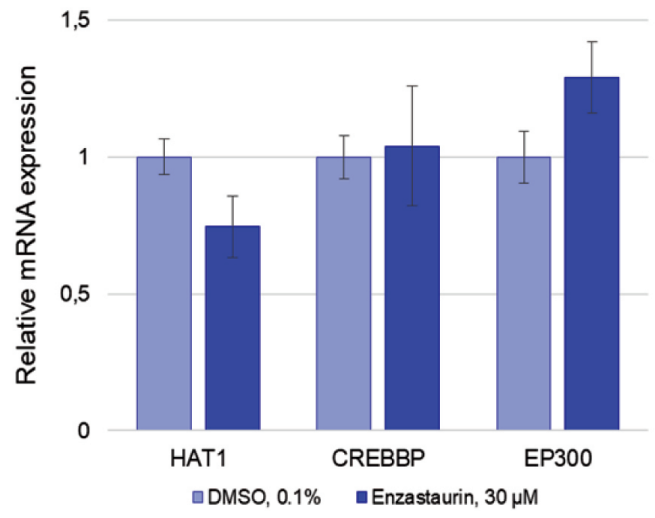

D.

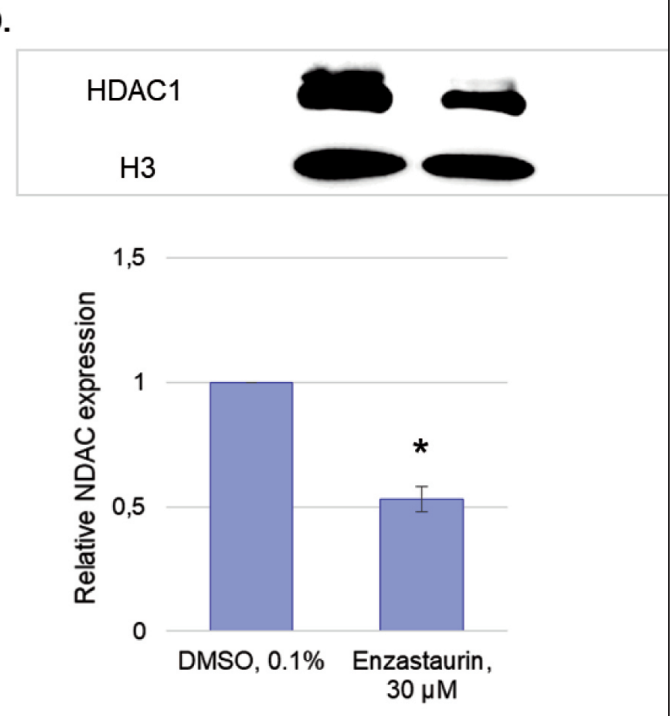

E.

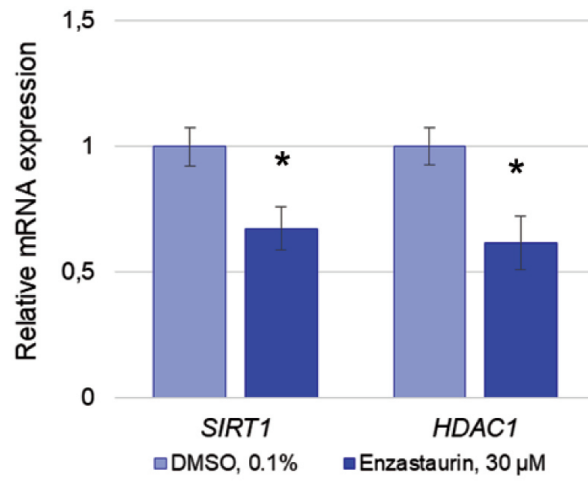

Рис. 2. Анализ эффектов энзастаурина на ацетилирование гистонов:

А. Влияние энзастаурина на ацетилирование гистона Н3, Вестерн-блоттинг и его денситометрический анализ; В. Влияние энзастаурина на тотальную активность ферментов семейства НАТ; С. Анализ влияния энзастаурина на экспрессию генов НАТs;

D. Анализ влияния энзастаурина на экспрессию белка HDAC1, Вестерн-блоттинг и его денситометрический анализ;

E. Анализ влияния энзастаурина на экспрессию генов SIRT1 и HDAC1 методом ОT-ПЦР в реальном времени. Для анализа данных использовали метод 2- $\Delta \Delta \mathrm{Ct}$, в качестве референсного гена использовали АСТВ, далее нормирование проводили по отрицательному контролю. Все результаты представлены в виде M \pm SD.

Примечание: * - различия статистически значимы по сравнению с контролем $(p<0,05)$.

Fig. 2. Analysis of the effect of enzastaurin on histone acetylation:

A. Effect of enzastaurin on $\mathrm{H} 3$ histone acetylation, Wetsern blotting and densitometric analysis; $\mathrm{B}$. Effect of enzastaurin on the total activity of the HAT family enzymes; C. Analysis of the effect of enzastaurin on the expression of HAT genes; D. Analysis of the effect of enzastaurin on the expression of HDAC1 protein, Wetsern blotting and densitometric analysis; E. Analysis of the effect of enzastaurin on the expression of SIRT1 and HDAC1 by real-time RT-PCR. The 2- $\triangle$ Ct method was used for data analysis, ACTB was used as a reference gene, and the samples were also normalized to the negative control. All data are presented as $M \pm S D$. Notees: ${ }^{*}$ - differences are statistically significant as compared to the control $(p<0.05)$ 
$D N M T 3 A$ and DNMT3B (by 2.5 -fold and 1.6 -fold, respectively), while the expression level of DNMT1, which was responsible for methylation during replication, remained unchanged.

Thus, screening of the epigenetic activity of five antitumor drugs from the group of protein kinase inhibitors (gefitinib, imatinib, pazopanib, ponatinib, and enzastaurin) allowed us to demonstrate for the first time the ability of enzastaurin to reactivate the expression of epigenetically repressed genes. Our original data concerning enzastaurin effects demonstrate both significant decrease of integrated DNA methylation and inhibition of de novo methyltransferases DNMT3A and $D N M T 3 B$ expression. Also, an increase in the level of histone acetylation under the action of enzastaurin was shown for the first time, which is consistent with our data on the inhibition of expression of histone deacetylases.

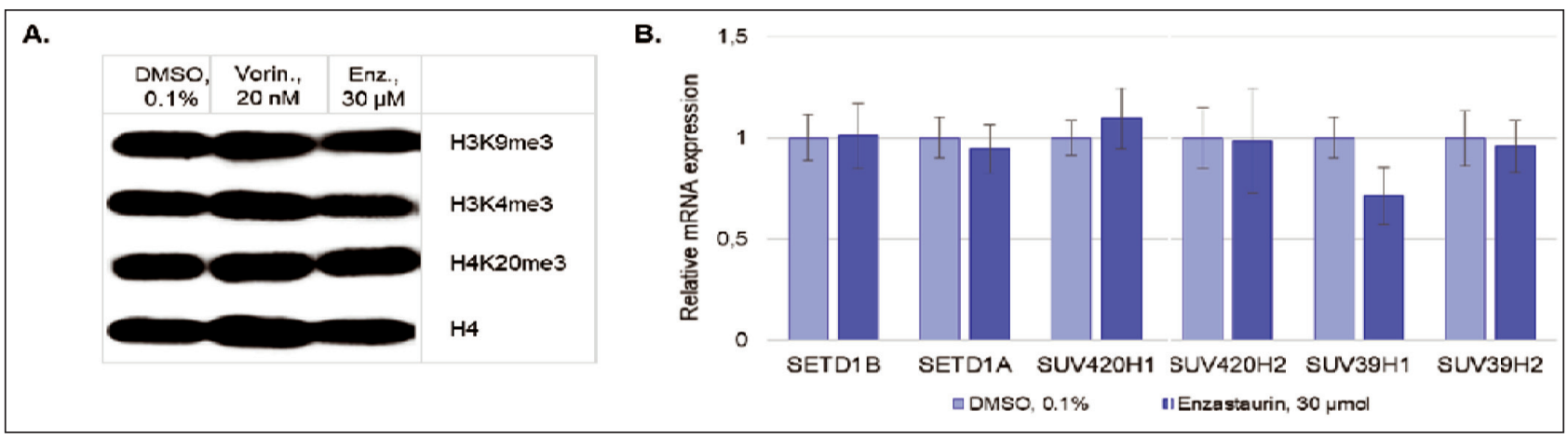

Рис. 3. Анализ эффектов энзастаурина на метилирование гистонов:

А. Влияние энзастаурина на метилирование гистонов Н3 и Н4, Вестерн-блоттинг; В. Анализ влияния энзастаурина на экспрессию генов HMTs методом ОТ-ПЦР в реальном времени. Для анализа данных использовали метод 2- $\Delta \Delta C \mathrm{Ct}$, в качестве референсного гена использовали АСТВ, далее нормирование проводили по отрицательному контролю. Все результаты представлены в виде $\mathrm{M} \pm \mathrm{SD}$.

Примечание: * - различия статистически значимы по сравнению с клетками контроля $(p<0,05)$

Fig. 3. Analysis of the effect of enzastaurin on histone methylation:

A. The effect of enzastaurin on the methylation of $\mathrm{H} 3$ and $\mathrm{H} 4$ histones, Wetsern blotting; $\mathrm{B}$. Analysis of the effect of enzastaurin on the expression of HMT genes by real-time RT-PCR. The 2- $\triangle \triangle$ Ct method was used for data analysis, ACTB was used as a reference gene, and the samples were also normalized to the negative control. All data are presented as $M \pm S D$.

Notes: * - differences are statistically significant as compared to the control $(p<0.05)$

A.

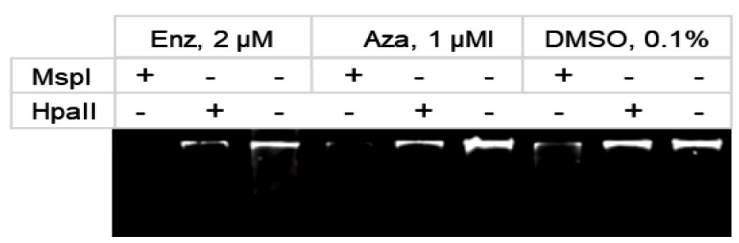

B.

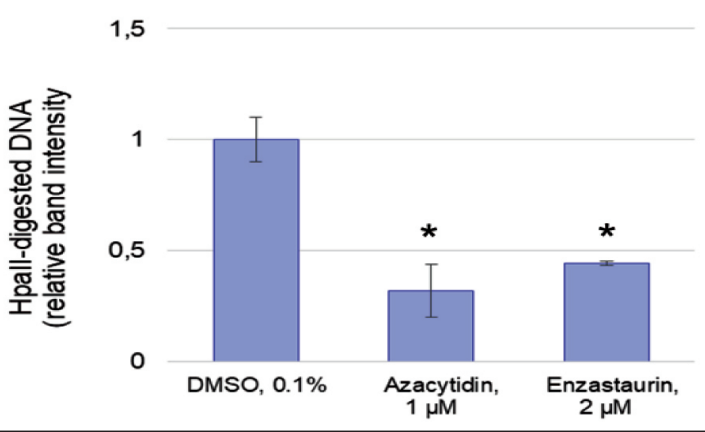

c.

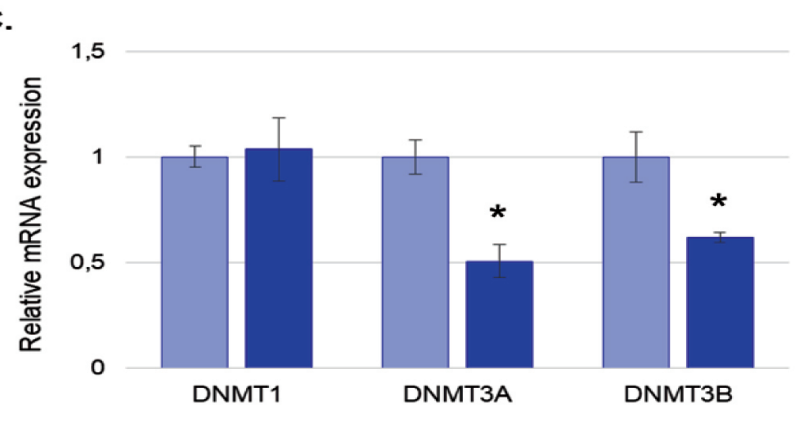

口DMSO, $0.1 \% \quad$ Enzastaurin, $30 \mu \mathrm{M}$

Рис. 4. Влияние энзастаурина на интегральное метилирование ДНК:

A. Электрофореграмма геномной ДНК, обработанной рестриктазами Hpall и Mspl; В. Денситометрический анализ полос Hраllрестрицированной ДНК относительно геномной ДНК; С. Анализ влияния энзастаурина на экспрессию генов DNMTs методом ОТ-ПЦР в реальном времени. Все результаты представлены в виде M \pm SD.

Примечание: * - различия статистически значимы по сравнению с контролем $(p<0,05)$

Fig. 4. The effect of enzastaurin on integrated DNA methylation:

A. Electrophoregram of the genomic DNA treated with restriction enzymes Hpall and Mspl; B. Densitometric analysis of the bands of Hpall-restricted DNA relative to the genomic DNA; C. Real-time RT-PCR analysis of the effect of enzastaurin on the expression of DNMT genes. All data are presented as $M \pm S D$.

Notes: * - differences are statistically significant as compared to the control $(p<0.05)$ 


\section{ЛИТЕРАTУPA/REFERENCES}

1. Cheng Y., He C., Wang M., Ma X., Mo F., Yang S., Han J., Wei X. Targeting epigenetic regulators for cancer therapy: mechanisms and advances in clinical trials. Signal Transduct Target Ther. 2019 Dec 17; 4: 62. doi: 10.1038/s41392-019-0095-0.

2. Ravegnini G., Sammarini G., Hrelia P., Angelini S. Key Genetic and Epigenetic Mechanisms in Chemical Carcinogenesis. Toxicol Sci. 2015 Nov; 148(1): 2-13. doi: 10.1093/toxsci/kfv165.

3. Han M., Jia L., Lv W., Wang L., Cui W. Epigenetic Enzyme Mutations: Role in Tumorigenesis and Molecular Inhibitors. Front Oncol. 2019 Mar 29; 9: 194. doi: 10.3389/fonc.2019.00194.

4. Gnyszka A., Jastrzebski Z., Flis S. DNA methyltransferase inhibitors and their emerging role in epigenetic therapy of cancer. Anticancer Res. 2013 Aug; 33(8): 2989-96.

5. Li Y. Seto E. HDACs and HDAC Inhibitors in Cancer Development and Therapy. Cold Spring Harb Perspect Med. 2016 Oct 3; 6(10): a026831. doi: 10.1101/cshperspect.a026831.

6. McClure J.J., Li X., Chou C.J. Advances and Challenges of HDAC Inhibitors in Cancer Therapeutics. Advances in Cancer Research. Academic Press. 2018. 183-211 p.

7. Zagni C. Chiacchio U., Rescifina A. Histone methyltransferase inhibitors: novel epigenetic agents for cancer treatment. Curr Med Chem. 2013; 20(2): 167-85. doi: 10.2174/092986713804806667.

8. Italiano A., Soria J.C., Toulmonde M., Michot J.M., Lucchesi C., Varga A., Coindre J.M., Blakemore S.J., Clawson A., Suttle B., McDonald A.A., Woodruff M., Ribich S., Hedrick E., Keilhack H., Thomson B., Owa T., Copeland R.A., Ho P.T.C., Ribrag V. Tazemetostat, an EZH2 inhibitor, in relapsed or refractory B-cell non-Hodgkin lymphoma and advanced solid tumours: a first-in-human, open-label, phase 1 study. Lancet Oncol. 2018 May; 19(5): 649-659. doi: 10.1016/S1470-2045(18)30145-1.

9. Verma N., Rai A.K., Kaushik V., Brünnert D., Chahar K.R., Pandey J. Goyal P. Identification of gefitinib off-targets using a structure-based systems biology approach; their validation with reverse docking and retrospective data mining. Sci Rep. 2016 Sep 22; 6: 33949. doi: 10.1038/ srep33949.

10. Ratovitski E.A. Anticancer Natural Compounds as Epigenetic Modulators of Gene Expression. Curr Genomics. 2017 Apr; 18(2): 175-205. doi: $10.2174 / 1389202917666160803165229$.

11. Chung F.F., Herceg Z. The Promises and Challenges of ToxicoEpigenomics: Environmental Chemicals and Their Impacts on the Epigenome. Environ Health Perspect. 2020 Jan; 128(1): 15001. doi: 10.1289/ EHP6104.

12. Katz R.A., Jack-Scott E., Narezkina A., Palagin I. Boimel P. Kulkosky J., Nicolas E., Greger J.G., Skalka A.M. High-frequency epigenetic repression and silencing of retroviruses can be antagonized by histone deacetylase inhibitors and transcriptional activators, but uniform reactivation in cell clones is restricted by additional mechanisms. J Virol. 2007 Mar; 81(6): 2592604. doi: 10.1128/JVI.01643-06.

13. Poleshko A., Einarson M.B. Shalginskikh N. Zhang R., Adams P.D. Skalka A.M., Katz R.A. Identification of a functional network of human epigenetic silencing factors. J Biol Chem. 2010 Jan 1; 285(1): 422-33. doi: 10.1074/jbc.M109.064667.

14. Shalginskikh N., Poleshko A., Skalka A.M., Katz R.A. Retroviral DNA methylation and epigenetic repression are mediated by the antiviral host protein Daxx. J Virol. 2013 Feb; 87(4): 2137-50. doi: 10.1128/ JVI.02026-12.

15. Varley K.E., Gertz J., Bowling K.M., Parker S.L., Reddy T.E., Pauli-Behn F., Cross M.K., Williams B.A., Stamatoyannopoulos J.A., Crawford G.E., Absher D.M., Wold B.J., Myers R.M. Dynamic DNA methylation across diverse human cell lines and tissues. Genome Res. 2013 Mar; 23(3): 555-67. doi: 10.1101/gr.147942.112.

16. Huang Y., Song H., Hu H., Cui L., You C., Huang L. Trichosanthin inhibits DNA methyltransferase and restores methylation-silenced gene expression in human cervical cancer cells. Mol Med Rep. 2012 Oct; 6(4): 872-8. doi: $10.3892 / \mathrm{mmr} .2012 .994$.

17. Mosmann T. Rapid colorimetric assay for cellular growth and survival: application to proliferation and cytotoxicity assays. J
Immunol Methods. 1983 Dec 16; 65(1-2): 55-63. doi: 10.1016/00221759(83)90303-4.

18. Shechter D., Dormann H.L., Allis C.D., Hake S.B. Extraction, purification and analysis of histones. Nat Protoc. 2007; 2(6): 1445-57. doi: $10.1038 /$ nprot.2007.202.

19. Li R., Hebert J.D., Lee T.A., Xing H., Boussommier-Calleja A., Hynes R.O., Lauffenburger D.A., Kamm R.D. Macrophage-Secreted TNF $\alpha$ and TGF $\beta 1$ Influence Migration Speed and Persistence of Cancer Cells in 3D Tissue Culture via Independent Pathways. Cancer Res. 2017 Jan 15; 77(2): 279-290. doi: 10.1158/0008-5472.CAN-16-0442.

20. Bhullar K.S., Lagarón N.O., McGowan E.M., Parmar I., Jha A., Hubbard B.P., Rupasinghe H.P.V. Kinase-targeted cancer therapies: progress, challenges and future directions. Mol Cancer. 2018; 17(1): 48. doi: 10.1186/ s12943-018-0804-2.

21. Kannaiyan R., Mahadevan D. A comprehensive review of protein kinase inhibitors for cancer therapy. Expert Rev Anticancer Ther. 2018 Dec; 18(12): 1249-1270. doi: 10.1080/14737140.2018.1527688.

22. Huang W.S., Metcalf C.A., Sundaramoorthi R., Wang Y., Zou D., Thomas R.M., Zhu X., Cai L., Wen D., Liu S., Romero J., Oi J., Chen I., Banda G., Lentini S.P., Das S., Xu Q., Keats J., Wang F., Wardwell S., Ning Y., Snodgrass J.T., Broudy M.I., Russian K., Zhou T., Commodore L., Narasimhan N.I., Mohemmad O.K., Iuliucci J., Rivera V.M., Dalgarno D.C., Sawyer T.K., Clackson T., Shakespeare W.C. Discovery of 3-[2-(imidazo[1,2-b]pyridazin-3-yl)ethynyl]-4-methyl-N- \{4-[(4-methylpiperazin-1-yl)methyl]-3-(trifluoromethyl)phenyl benzamide (AP24534), a potent, orally active pan-inhibitor of breakpoint cluster region-abelson (BCR-ABL) kinase including the T315I gatekeeper mutant. J Med Chem. 2010 Jun 24; 53(12): 4701-19. doi: 10.1021/jm100395q.

23. O'Hare T., Shakespeare W.C., Zhu X., Eide C.A., Rivera V.M., Wang F., Adrian L.T., Zhou T., Huang W.S., Xu Q., MetcalfC.A., Tyner J.W., Loriaux M.M., Corbin A.S., Wardwell S., Ning Y., Keats J.A., Wang Y., Sundaramoorthi R., Thomas M., Zhou D., Snodgrass J., Commodore L., Sawyer T.K., Dalgarno D.C., Deininger M.W., Druker B.J., Clackson T. AP24534, a pan-BCR-ABL inhibitor for chronic myeloid leukemia, potently inhibits the T315I mutant and overcomes mutation-based resistance. Cancer Cell. 2009 Nov 6; 16(5): 401-12. doi: 10.1016/j. ccr.2009.09.028

24. Nowakowski G.S., Zhu J., Zhang Q., Brody J., Sun X., Maly J., Song Y., Rizvi S., Song Y., Lansigan F., Jing H., Cao J., Lue J.K., Luo W., Zhang L., Li L., Han I., Sun J., Jivani M., Liu Y., Heineman T., Smith S.D. ENGINE: a Phase III randomized placebo controlled study of enzastaurin/ $\mathrm{R}-\mathrm{CHOP}$ as frontline therapy in high-risk diffuse large B-cell lymphoma patients with the genomic biomarker DGM1. Future Oncol. 2020 May; 16(15): 991-9. doi: 10.2217/fon-2020-0176.

25. Wilting R.H., Dannenberg J.H. Epigenetic mechanisms in tumorigenesis, tumor cell heterogeneity and drug resistance. Drug Resist Updat. 2012; 15(1-2): 21-38. doi: 10.1016/j.drup.2012.01.008.

26. Delcuve G.P., Khan D.H., Davie J.R. Roles of histone deacetylases in epigenetic regulation: emerging paradigms from studies with inhibitors. Clin Epigenetics. 2012 Mar 12; 4(1): 5. doi: 10.1186/1868-7083-4-5.

27. Rifaï K., Judes G., Idrissou M., Daures M., Bignon Y.J., PenaultLlorca F., Bernard-Gallon D. SIRT1-dependent epigenetic regulation of H3 and $\mathrm{H} 4$ histone acetylation in human breast cancer. Oncotarget. 2018 Jul 17; 9(55): 30661-30678. doi: 10.18632/oncotarget.25771.

28. Volkel P., Angrand P.O. The control of histone lysine methylation in epigenetic regulation. Biochimie. 2007; 89(1): 1-20. doi: 10.1016/j. biochi.2006.07.009.

29. Koch A., Joosten S.C., Feng Z., de Ruijter T.C., Draht M.X., Melotte V., Smits K.M. VeeckJ., Herman J.G., Van Neste L., Van Criekinge W. De Meyer T., van Engeland M. Analysis of DNA methylation in cancer: location revisited. Nat Rev Clin Oncol. 2018; 15(7): 459-466. doi: 10.1038/ s41571-018-0004-4.

30. Patnaik S., Anupriya. Drugs Targeting Epigenetic Modifications and Plausible Therapeutic Strategies Against Colorectal Cancer. Front Pharmacol. 2019; 10: 588. doi: 10.3389/fphar.2019.00588.

Поступила/Received 20.04.2020

Принята в печать/Accepted 19.05.2020

\section{СВЕДЕНИЯ ОБ АВТОРАХ}

Максимова Варвара Павловна, младший научный сотрудник отдела химического канцерогенеза, НМИЦ онкологии им. Н.Н. Блохина (г. Москва, Россия). E-mail: lavarvar@gmail.com. SPIN-код: 5090-7297. Researcher ID (WOS): S-7580-2019. Author ID (Scopus): 57195322203. ORCID: 0000-0003-0896-2952.

Макусь Юлия Валерьевна, студент, МИРЭА - Российский технологический университет; практикант отдела химического канцерогенеза, НМИЦ онкологии им. Н.Н. Блохина (г. Москва, Россия). Researcher ID (WOS): AAK-2145-2020. ORCID: 00000001-6820-4198. 
Усалка Ольга Геннадьевна, студент, МГМУ им. И.М. Сеченова; практикант отдела химического канцерогенеза, НМИЦ онкологии им. Н.Н. Блохина (г. Москва, Россия). Researcher ID (WOS): AAK-2008-2020. ORCID: 0000-0001-9525-0771.

Лылова Евгения Сергеевна, лаборант-исследователь отдела химического канцерогенеза, ФГБУ «НМИЦ онкологии им. Н.Н. Блохина» (г. Москва, Россия). SPIN-код: 2739-8808. Author ID (Scopus): 57202944330.ORCID: 0000-0001-6388-1624.

Бугаева Полина Евгеньевна, студент, МГМУ им. И.М. Сеченова; практикант отдела химического канцерогенеза, НМИЦ онкологии им. Н.Н. Блохина (г. Москва, Россия). ORCID: 0000-0001-8745-2568.

Жидкова Екатерина Михайловна, младший научный сотрудник отдела химического канцерогенеза, НМИЦ онкологии им. Н.Н. Блохина (г. Москва, Россия). SPIN-код: 6899-7280. Researcher ID (WOS): AAK-3626-2020. Author ID (Scopus): 57195322730. ORCID: 0000-0003-3318-9391.

Федоров Дмитрий Андреевич, студент, МГМУ им. И.М. Сеченова; лаборант-исследователь отдела химического канцерогенеза, НМИЦ онкологии им. Н.Н. Блохина (г. Москва, Россия). Researcher ID (WOS): AAK-1914-2020. ORCID: 0000-0002-62322078.

Лизогуб Ольга Павловна, студент, МГМУ им. И.М. Сеченова; лаборант-исследователь отдела химического канцерогенеза, НМИЦ онкологии им. Н.Н. Блохина (г. Москва, Россия). Researcher ID (WOS): AAK-1935-2020. ORCID: 0000-0003-4788-0474. Лесовая Екатерина Андреевна, доктор биологических наук, старший научный сотрудник отдела химического канцерогенеза, НМИЦ онкологии им. Н.Н. Блохина (г. Москва, Россия). SPIN-код: 7593-2167. Researcher ID (WOS): J-7790-2015. Author ID (Scopus): 583044. ORCID: 0000-0002-1967-9637.

Белицкий Геннадий Альтерович, доктор медицинских наук, профессор, ведущий научный сотрудник отдела химического канцерогенеза, НМИЦ онкологии им. Н.Н. Блохина (г. Москва, Россия). SPIN-код: 4037-0033. Researcher ID (WOS): L-30622015. Author ID (Scopus): 107231.

Якубовская Марианна Геннадиевна, доктор медицинских наук, заведующая отделом химического канцерогенеза, НМИЦ онкологии им. Н.Н. Блохина (г. Москва, Россия). SPIN-код: 6858-3880. Researcher ID (WOS): R-6984-2016. Author ID (Scopus): 583045. ORCID: 0000-0002-9710-8178.

Кирсанов Кирилл Игоревич, кандидат биологических наук, заведующий лабораторией канцерогенных веществ отдела химического канцерогенеза, НМИЦ онкологии им. Н.Н. Блохина (г. Москва, Россия). SPIN-код: 7329-7263. Researcher ID (WOS): L-3062-2015. Author ID (Scopus): 184421. ORCID: 0000-0002-8599-6833.

\section{ВКЛАД АВТОРОВ}

Максимова Варвара Павловна: эпигенетический анализ, анализ данных, написание рукописи.

Макусь Юлия Валерьевна: исследование уровня гистоновых модификаций и уровня экспрессии HDAC1.

Усалка Ольга Геннадьевна: анализ метилирования ДНК.

Лылова Евгения Сергеевна: анализ экспрессии регуляторных белков.

Бугаева Полина Евгеньевна: исследование уровня экспрессии регуляторных белков.

Жидкова Екатерина Михайловна: работа над иллюстрациями.

Федоров Дмитрий Андреевич: изучение уровня гистоновых модификаций.

Лизогуб Ольга Павловна: анализ уровня гистоновых модификаций.

Лесовая Екатерина Андреевна: статистическая обработка.

Белицкий Геннадий Альтерович: анализ данных, написание статьи.

Якубовская Марианна Геннадиевна: дизайн исследования, анализ данных, подготовка рукописи.

Кирсанов Кирилл Игоревич: дизайн исследования, анализ данных, подготовка рукописи.

\section{Информация о финансировании}

Работа выполнена при финансовой поддержке РНФ (грант № 18-75-00115).

Информация о конфликте интересов

Авторы объявляют, что у них нет конфликта интересов.

\section{ABOUT THE AUTHORS}

Varvara P. Maksimova, Junior Researcher, Department of Chemical Carcinogenesis, N.N. Blokhin NMRCO (Moscow, Russia). E-mail: lavarvar@gmail.com.

Julia V. Makus, Intern, Department of Chemical Carcinogenesis, N.N. Blokhin NMRCO (Moscow, Russia).

Olga G. Usalka, Intern, Department of Chemical Carcinogenesis, N.N. Blokhin NMRCO (Moscow, Russia).

Eugenia S. Lylova, Laboratory Assistant, Department of Chemical Carcinogenesis, N.N. Blokhin NMRCO (Moscow, Russia).

Polina E. Bugaeva, Intern, Department of Chemical Carcinogenesis, N.N. Blokhin NMRCO (Moscow, Russia).

Ekaterina M. Zhidkova, Junior Researcher, Department of Chemical Carcinogenesis, N.N. Blokhin NMRCO (Moscow, Russia).

Dmitry A. Fedorov, Laboratory Assistant, Department of Chemical Carcinogenesis, N.N. Blokhin NMRCO (Moscow, Russia).

Olga P. Lizogub, Laboratory Assistant, Department of Chemical Carcinogenesis, N.N. Blokhin NMRCO (Moscow, Russia).

Ekaterina A. Lesovaya, PhD, Senior Researcher, Department of Chemical Carcinogenesis, N.N. Blokhin NMRCO (Moscow, Russia).

Gennady A. Belitsky, MD, DSc, Professor, Leading Researcher, Department of Chemical Carcinogenesis, N.N. Blokhin NMRCO (Moscow, Russia). 
Marianna G. Yakubovskaya, MD, DSc, Head of Department of Chemical Carcinogenesis, N.N. Blokhin NMRCO (Moscow, Russia).

Kirill I. Kirsanov, PhD, Head of Laboratory of Chemical Carcinogens, N.N. Blokhin NMRCO (Moscow, Russia).

\section{AUTHOR CONTRIBUTION}

Varvara P. Maksimova: study protocols, epigenetic analyses, data analyses, drafting of manuscript.

Julia V. Makus: analysis of the levels of histone modifications and HDAC1.

Olga G. Usalka: DNA methylation analysis.

Eugenia S. Lylova: analysis of gene expression of regulatory enzymes.

Polina E. Bugaeva: analysis of gene expression of regulatory enzymes.

Ekaterina M. Zhidkova: work on illustrations.

Dmitry A. Fedorov: analysis of histone modifications level.

Olga P. Lizogub: analysis of histone modifications level.

Ekaterina A. Lesovaya: statistical analyses.

Gennady A. Belitsky: data analysis, critical revision of manuscript for important intellectual content.

Marianna G. Yakubovskaya: conception of the work and experiments design; interpretation of the results; manuscript editing.

Kirill I. Kirsanov: conception of the work and experiments design; interpretation of the results; manuscript editing.

\section{Funding}

The Russian Science Foundation (project 187500 115) supported this work.

\section{Conflict of interest}

The authors declare that they have no conflict of interest. 